\title{
POTENSI LARUTAN CHITOSAN 0,2\% SEBAGAI ALTERNATIF BAHAN IRIGASI DALAM PERAWATAN SALURAN AKAR GIGI (Kajian Pustaka)
}

\author{
Sinta Deviyanti* \\ Bagian Konservasi Fakultas Kedokteran Gigi Univ.Prof.Dr.Moestopo (Beragama)
}

\begin{abstract}
ABSTRAK
Irigasi dan instrumentasi merupakan salah satu faktor yang berperan penting dalam perawatan saluran akar gigi. Penggunaan instrumen manual dan instrumen yang digerakkan mesin, akan menghasilkan smear layer yang menutupi dinding saluran akar dan tubuli dentin yang terbuka.Pembersihkan debridement secara menyeluruh serta pembersihan smear layer merupakan landasan untuk mencapai keberhasilan perawatan saluran akar gigi. Irigasi dengan sodium hipoklorit $(\mathrm{NaOCl})$ yang dikombinasi dengan bahan khelasi seperti Ethylenediaminetetraacetic (EDTA) telah direkomendasikan untuk pembersihan komponen organik dan komponen inorganik dari smear layer secara efektif. Namun, EDTA dapat bersifat erosif terhadap dentin, konsekuensinya mempengaruhi sifat kekerasan, permeabilitas dan pelarutan dentin di bagian dalam akar gigi. Penggunaan $\mathrm{NaOCl}$ tidak mampu membersihkan smear layer, karena hanya efektif terhadap debris organik. Oleh karena itu,dibutuhkan penelitian untuk mencari larutan irigasi yang lebih kompatibel, efesien membersihkan smear layer dan menyebabkan erosi dentin yang lebih rendah. Saat ini, chitosan telah diteliti di bidang kedokteran gigi.Chitosan adalah polisakarida alamiah, berasal dari deasetilasi chitin yang terdapat pada cangkang kepiting dan udang. Chitosan memiliki kemampuan khelasi, biokompatibel, biodegradasi, bioadhesi dan tidak toksik terhadap tubuh manusia. Hasil-hasil penelitian terbaru telah menyimpulkan bahwa irigasi akhir dengan larutan Chitosan $0,2 \%$ setelah irigasi dengan larutan $\mathrm{NaOCl}$, lebih efesien dalam membersihkan smear layer dibanding bahan irigasi lainnya dan menyebabkan erosi lebih sedikit pada dentin akar gigi. Chitosan dapat dipertimbangkan sebagai alternatif bahan irigasi dalam perawatan saluran akar gigi karena memiliki kemampuan khelasi pada dentin saluran akar gigi.
\end{abstract}

Kata kunci : Chitosan, irigasi, smear layer, kemampuan khelasi, perawatan saluran akar gigi

\begin{abstract}
Irrigation and instrumentation is one another factor which play a critical role in root canal treatment. Used of manual and rotary instrumentation produces smear layer that covers canal wall an the openings of the dentinal tubules. Complete debridement with smear layer removal are essential measurement for achieving a successful outcome of root canal treatment. Irrigation with sodium hypochlorite $(\mathrm{NaOCl})$ combined with chelating agent like Ethylenediaminetetraacetic acid (EDTA) has been recommended for the effective removal of organic and inorganic components from the smear layer. However, EDTA can be erosive in dentin, consequently affects the characteristic hardness, permeability and solubility of dentin intraradicular. Used of $\mathrm{NaOCl}$ is not able to remove the smear layer, thoroughly because it is effective only on organic debris. Therefore, the search for irrigation solution more biocompatible, efficient in smear layer removed and caused less erosive in dentin has been needed. Nowadays, Chitosan has been observed in dentistry field. Chitosan is a natural polysaccharide, coming from the deacetylation of chitin, which is obtain from the shells of crabs and shrimp.Chitosan has a high chelating ability,biocompatibility, biodegradability, bioadhesion and non toxicity to the human body. Recent studies concluded that final irrigation with $0,2 \%$ Chitosan solution after irrigation with $\mathrm{NaOCl}$ solution, was more efficient in smear layer removed than another irrigation agent and causing little erosion on root dentin. The property of Chitosan solution $0,2 \%$ that provide its chelating capacity on root dentine, can be considered as alternative irrigation agent in root canal treatment.
\end{abstract}

Key word : Chitosan, irrigation,smear layer, chelating ability, root canal treatment

\section{PENDAHULUAN}

I nstrumentasi dan irigasi saluran akar gigi sebagai bagian dari tahap pembersihan dan pembentukan pembentukan saluran akar gigi, merupakan salah satu faktor yang berperan penting dalam keberhasilan perawatan saluran akar gigi. Penggunaan instrumen manual terutama rotary (digerakkan oleh mesin) pada tahap tersebut, akan menghasilkan smear layer yang menutupi dinding saluran akar gigi maupun tubuli dentin yang terbuka di sepanjang dinding saluran akar 
gigi. ${ }^{1,2,3}$ Keberadaan smear layer dalam saluran akar gigi akan menguntungkan adhesi dan kolonisasi mikroorganisme, menghalangi aksi larutan disinfektan serta menghambat medikamen dalam saluran akar gigi berpenetrasi ke tubuli dentin di dinding saluran akar gigi. Smear layer juga akan menghalangi adaptasi sealer (semen pelapis dinding saluran akar gigi) dan bahan pengisi saluran akar gigi ke lapisan dentin di dinding saluran akar gigi. ${ }^{1,4}$ Penggunaan bahan irigasi diperlukan untuk membilas debris, membunuh mikroorganisme dan membersihkan komponen organik maupun inorganik dari smear layer yang terdapat di dalam saluran akar gigi selama tahap perawatan tersebut. ${ }^{2}$ Di antara berbagai bahan irigasi, larutan sodium hipoklorit ( $\mathrm{NaOCl})$ konsentrasi 0,5\% - 5,25\% masih menjadi gold standard karena efektif melarutkan jaringan dan bersifat antiseptik. Namun, larutan irigasi $\mathrm{NaOCl}$ memiliki keterbatasan yaitu tidak mampu membersihkan smear layer secara menyeluruh karena hanya efektif untuk membersihkan komponen debris organik sehingga masih memerlukan penggunaan bahan dekalsifikasi untuk melengkapi fungsinya. Larutan $\mathrm{NaOCl}$ juga bersifat toksik terhadap jaringan periapikal dan dianggap dapat mendegradasi sifat mikromekanikal dari dentin di dinding saluran akar gigi. ${ }^{2,3,5,6}$ Bahan irigasi selanjutnya yang efektif dan paling umum digunakan untuk membersihkan komponen inorganik smear layer di saluran akar gigi tersebut adalah larutan Ethylenediaminetetraacetic acid (EDTA) konsentrasi 17\%. Larutan EDTA sebagai bahan irigasi dan khelasi merupakan suatu tiruan asam amino dengan pH 7 yang tidak memiliki efek anti bakteri ${ }^{2,3,4}$.Oleh karena itu, kombinasi bahan irigasi $\mathrm{NaOCl}$ dan EDTA, telah direkomendasikan penggunaannya untuk membersihkan smear layer secara menyeluruh. ${ }^{3}$ Namun demikian, EDTA bersifat toksik terhadap jaringan periapikal dan dapat menyebabkan demineralisasi yang meluas pada dentin dinding saluran akar gigi.4,6 Penggunaan EDTA juga dapat menyebabkan perubahan sifat biomekanik lapisan dentin di dinding saluran akar gigi. Perubahan rasio kalsium-fosfat $(\mathrm{Ca} / \mathrm{P})$ di dentin dinding saluran akar oleh EDTA juga dapat merubah proporsi komponen organik dan inorganik yang berdampak mempengaruhi kekerasan, permeabilitas serta solubilitas dentin. ${ }^{7}$ Sumber EDTA juga tidak dijumpai secara alamiah sehingga dianggap sebagai polutan. Mengingat masih dijumpainya kelemahan dari bahan irigasi NaOCL dan EDTA tersebut di atas, masih perlu dicari dan dikembangkan alternatif bahan irigasi yang bersifat biokompatibel, efektif dan aman sehingga dapat meminimalisasi dampak yang merugikan struktur gigi maupun jaringan periapikal. ${ }^{4}$

Saat ini telah dikembangkan dan terus diteliti larutan chitosan $0,2 \%$ sebagai alternatif bahan irigasi dalam perawatan saluran akar gigi. Chitosan merupakan suatu polisakarida alamiah yang saat ini banyak mendapat perhatian di bidang kedokteran gigi karena bersifat biokompatibel, biodegradasi, bioadhesi, memiliki aktivitas anti mikroba dan tidak bersifat toksik terhadap tubuh manusia. Chitosan juga memiliki kemampuan khelasi yang tinggi terhadap berbagai ion logam pada kondisi asam. Chitosan diperoleh dari proses deasetilasi chitin yang terdapat di cangkang udang dan kepiting sehingga secara ekologis memiliki daya tarik untuk dimanfaatkan dalam berbagai aplikasi karena tersedia secara berlimpah di alam dan biaya produksinya murah $2,4,8,9$.

Tujuan penulisan makalah ini adalah untuk memberi informasi dan mengkaji tentang potensi penggunaan larutan chitosan $0,2 \%$ sebagai alternatif bahan irigasi pada perawatan saluran akar gigi. Manfaat penulisan makalah ini diharapkan dapat memperluas wawasan pengetahuan dan menjadi dasar pertimbangan pembaca khususnya praktisi di bidang kedokteran gigi, untuk memilih dan mengembangkan bahan irigasi saluran akar gigi yang lebih efektif, aman dan ekonomis sehingga dapat membantu meningkatkan keberhasilan perawatan saluran akar gigi secara umum.

\section{KAJIAN PUSTAKA}

\section{A. Debris dan Smear Layer di Saluran Akar Gigi}

Debris adalah serpihan dentin atau sisa jaringan pulpa vital maupun nekrotik yang terdapat di dinding saluran akar gigi. Smear layer adalah suatu permukaan film atau debris yang tertahan di dentin atau permukaan lain setelah instrumentasi dengan files (jarum kikir) endodontik maupun instrumen rotary (digerakkan mesin). Smear layer terdiri dari partikel dentin, sisa-sisa jaringan pulpa vital maupun nekrotik serta komponen bakteri dan produk metabolitnya ${ }^{10}$. Bahan organik dan inorganik yang dihasilkan selama tahap pembersihan dan pembentukan saluran akar gigi tersebut, dapat tertimbun di saluran akar tambahan (accessory canals), fins, isthmuses serta dinding saluran akar gigi sehingga membentuk smear layer yang tidak beraturan. Smear layer sebagai lapisan di bagian permukaan dinding saluran akar gigi memiliki ketebalan 1-5 $\mu \mathrm{m}$ dan dapat tersimpan dalam tubuli dentin. Ukuran partikel penyusun smear layer berkisar antara 0,5-15 $\mu \mathrm{m},{ }^{1,6}$

Belum ada kesepakatan untuk membersihkan smear layer sebelum obturasi saluran akar gigi. Keuntungan dan kerugian dari pembersihan smear layer masih kontroversi. Namun bukti secara umum mendukung perlunya pembersihan smear layer sebelum dilakukannya tahap obturasi saluran akar gigi karena debris organik dari smear layer dapat menjadi substrat untuk pertumbuhan bakteri. Smear layer juga dianggap dapat menghambat kontak antara sealer dengan dinding saluran akar gigi serta mempengaruhi adaptasi bahan obturasi dengan dinding saluran akar gigi yang memungkinkan terjadinya kebocoran (leakage). Mikroorganisme yang mampu bertahan hidup di tubuli dentin dari dinding saluran akar gigi, dapat menggunakan smear layer tersebut sebagai substrat untuk kelangsungan hidupnya. Keberadaan smear layer juga dapat menmpengaruhi aksi dan efektivitas bahan irigasi saluran akar gigi serta menghalangi penetrasi medikamen 
ke tubuli dentin di dinding saluran akar gigi. Pembersihan smear layer akan menyebabkan adaptasi yang baik dari bahan pengisi saluran akar gigi ke dinding saluran akar gigi serta meningkatkan adhesi dan penetrasi sealer ke tubuli dentin. Selanjutnya, pembersihan smear layer juga akan mengurangi kebocoran di bagian ujung akar gigi. ${ }^{1,6}$

\section{B. Definisi dan Fungsi Bahan Irigasi dalam Perawatan Saluran Akar Gigi}

Bahan irigasi adalah cairan medikasi yang digunakan untuk membilas kavitas dan saluran akar gigi. ${ }^{10}$ Penggunaan larutan irigasi melalui aksi pembilasan selama dan setelah instrumentasi pada perawatan saluran akar gigi, berfungsi untuk melarutkan sisa-sisa jaringan organik pulpa dan kolagen dentin serta jaringan inorganik, membuang debris atau serpihan dentin yang dihasilkan dari aksi mekanik instrumentasi sehingga menghindari penumpukan debris maupun ekstrusi debris ke daerah periapikal. Bahan irigasi juga berfungsi mencegah pembentukan smear layer selama instrumentasi atau melarutkan smear layer yang telah terbentuk sehingga tubuli dentin di dinding saluran akar gigi menjadi terbuka. Bahan irigasi juga dapat berfungsi membantu membersihkan dan mendisinfeksi daerah saluran akar gigi yang tidak dapat diakses oleh instrumen endodontik serta sebagai pelumas untuk memfasilitasi instrumen files manual selama tahap pembersihan dan pembentukan saluran akar gigi, termasuk membantu penjajakan awal saluran akar gigi terutama pada saluran akar gigi yang sempit dan tersumbat. 5,6,10,11 Penggunaan larutan irigasi secara tunggal, belum ada yang mampu memenuhi kebutuhan fungsi dan syarat ideal dari bahan irigasi. Irigasi yang optimal didasarkan pada penggunaan dua atau beberapa jenis bahan irigasi untuk mencapai tujuan irigasi yang efektif dan aman. ${ }^{1,5}$

\section{Berbagai Bahan Irigasi Saluran Akar Gigi Secara Umum}

Berbagai bahan irigasi dalam perawatan saluran akar gigi meliputi :

1. Sodium hipoklorit (NaOCL)

Merupakan jenis bahan irigasi yang paling umum digunakan melalui mekanisme pembilasan debris dari saluran akar dengan kemampuan anti bakteri berspektrum luas sebagai efek dilepaskannya klorin dan oksigen. Sebagai bahan proteolitik non spesifik, larutan irigasi NaOCL memiliki kemampuan melarutkan jaringan pulpa vital maupun nekrotik, namun tidak mampu membersihkan smear layer di saluran akar gigi ${ }^{5.6 .11}$. Larutan irigasi NaOCL juga memiliki kemampuan lubrikasi, harganya relatif murah dan mudah diperoleh. Sebagai bahan irigasi saluran akar gigi, larutan $\mathrm{NaOCL}$ digunakan pada konsentrasi 0,5\%-5,25\%. Penggunaan konsentrasi $\mathrm{NaOCl} 2,5 \%$ berpotensi mengurangi toksisitas tanpa mengurangi kemampuan pelarutan jaringan dan aktivitas antimikroba. Penggunaan larutan irigasi NaOCL dengan konsentrasi tinggi, memiliki toksisitas yang lebih besar dibandingkan konsentrasi yang rendah. Ekstrusi larutan irigasi $\mathrm{NaOCL}$ ini ke jaringan periapikal perlu dihindari karena sifatnya yang toksik ${ }^{6,10}$.

2. Chlorhexidine gluconate (CHX)

Larutan irigasi CHX dengan konsentrasi 2\% memiliki efek antimikroba berspektrum luas yang baik dengan aksi antimikroba yang bertahan lama karena mampu berikatan dengan dentin dinding saluran akar gigi. Larutan irigasi CHX tidak bersifat toksik dan tidak mengiritasi jaringan periapikal serta baunya tidak seperti larutan irigasi NaOCL yang berbau tidak enak. Sifat larutan irigasi CHX yang tidak menyebabkan erosi terhadap dentin di dinding saluran akar gigi sebagaimana pada larutan irigasi NaOCL, menyebabkan CHX digunakan sebagai larutan pembilas akhir setelah penggunaan larutan EDTA. Namun demikian, larutan irigasi CHX tidak memiliki kemampuan melarutkan jaringan organik dan inorganik dalam saluran akar gigi sehingga tidak dapat menggantikan fungsi larutan irigasi $\mathrm{NaOCL}^{5,10,11}$.

3. Ethylenediaminetetraacetic acid (EDTA)

EDTA merupakan suatu asam aminopolycarboxylic yang hampir tidak berwarna dan larut dalam air. Sebagai larutan irigasi, EDTA yang juga sebagai suatu bahan khelasi,mampu bereaksi dengan ion kalsium di dentin dinding saluran akar gigi untuk membentuk khelasi kalsium yang dapat larut dan membersihkan bagian mineral dari smear layer ${ }^{6,10}$. Penggunaan EDTA tunggal, secara normal tidak dapat efektif membersihkan smear layer. Perlu ditambahkan komponen proteolitik seperti $\mathrm{NaOCl}$ untuk membersihkan komponen organik dari smear layer yang tersisa dari penggunaan larutan irigasi EDTA tersebut ${ }^{1,6,10}$. Penggunaan larutan irigasi EDTA dengan konsentrasi $17 \%$ selama 1 menit yang diikuti dengan pembilasan akhir menggunakan larutan irigasi $\mathrm{NaOCL}$ telah direkomendasikan untuk digunakan dalam perawatan saluran akar gigi, namun dapat menyebabkan demineralisasi yang meluas pada dentin dinding saluran akar gigi ${ }^{6}$. Penggunaan EDTA sebagai larutan irigasi tunggal, tidak memiliki efek antibakteri dan harganya masih relatif mahal ${ }^{5}$.

4. MTAD (Mixture Tetracycline isomer-Acid-Detergent) Larutan irigasi MTAD dengan komposisi tetrasiklin, asam sitrat dan deterjen, digunakan selama 5 menit sebagai pembilas terakhir yang efektif untuk membersihkan smear layer setelah penggunaan larutan irigasi NaOCL 1,3\% di saluran akar gigi. MTAD memiliki daya antimikroba yang lebih baik dibandingkan NaOCL. Kemampuan demineralisasi dentin MTAD lebih cepat dibandingkan EDTA 17\% serta tidak menyebabkan perubahan bermakna dari struktur tubuli dentin di dinding saluran akar gigi 1,6,11

\section{Definisi, Sumber, Struktur, Sifat dan Fungsi Chitosan}

Chitosan merupakan suatu kopolimer 
aminopolisakarida kationik alamiah dari glukosamin dan $\mathrm{N}$-asetilglukosamin dengan berat molekul berkisar antara 1,000,000 sampai 3,000,000 2,4. Chitosan dapat diperoleh dari proses deasetilasi chitin yang terdapat pada cangkang udang dan kepiting ${ }^{4}$. Struktur kimia Chitosan sebagai suatu kopolimer terdiri dari unit $\beta-(1->4)-2-$ acetamido-D-glucose dan $\beta$-(1->4)-2-amino- $D$ glucose. Chitosan memiliki tiga jenis gugus reaktif fungsional yaitu gugus amino/acetamido, gugus hidroksil primer dan gugus hidroksil sekunder pada posisi C-2,C-3,C-6. Komponen amino yang tersebar secara acak, merupakan faktor utama yang berkontribusi pada perbedaan struktur sifat fisik-kimiawi. Gugus amino fungsional berkorelasi dengan fungsi khelasi, flokulasi dan biologis. Chitosan memiliki tiga jenis kristal yaitu $\alpha, \beta, \gamma$ yang dapat diidentifikasi dari x-ray. Kristal chitosan jenis $\alpha$, umumnya diperoleh dari cangkang udang dan kepiting ${ }^{12}$. Bentuk fisik chitosan dapat berupa film, serat, butiran, bubuk atau partikel nano. ${ }^{2}$

Chitosan bersifat biokompatibel, bioadhesi,dapat diperbaharui, memiliki aktivitas anti mikroba dan tidak bersifat toksik terhadap tubuh manusia. Chitosan pada $\mathrm{pH}$ asam juga memiliki kemampuan khelasi yang besar terhadap berbagai ion logam serta merupakan biopolimer yang mampu didegradasi untuk berbagai aplikasi terutama di bidang farmasi, makanan dan kosmetik . Aplikasi chitosan di bidang kedokteran gigi yang telah diteliti antara lain berfungsi sebagai modulator inflamasi, membantu regenerasi periodontal pada intraosseus defects, membantu medikasi saluran akar gigi, sebagai bahan anti mikroba dalam bahan bonding dan tumpatan resin komposit ${ }^{9}$. Aplikasi chitosan juga telah dimanfaatkan untuk perawatan tubuli dentin yang terinfeksi pada kasus direct pulp capping serta untuk regenerasi jaringan pulpa yang cedera. Selanjutnya, chitosan gel $0,2 \%$ diketahui memiliki sifat anti jamur. Berbagai fungsi chitosan tersebut tergantung dari struktur kimia dan ukuran molekulnya. . $, 3,12^{2}$

\section{E.Efektifitas Larutan Irigasi Chitosan 0,2\% Pada Perawatan Saluran Akar Gigi}

Penelitian in vitro oleh Silva PV (2012) menggunakan scanning electron microscope telah memperlihatkan bahwa penggunaan $10 \mathrm{ml}$ larutan irigasi $\mathrm{NaOCl} 1 \%$ dilanjutkan dengan $5 \mathrm{ml}$ larutan Chitosan $0,2 \%$ selama 3 menit sebagai bahan irigasi terakhir pada 12 buah spesimen gigi caninus rahang atas permanen manusia, mampu membersihkan smear layer secara menyeluruh tanpa keberadaan smear plugs hingga tubuli dentin yang terbuka terlihat secara jelas dengan erosi ringan pada dentin peritubulus dibandingkan aplikasi larutan Chitosan 0,1\% (masih tampak tertutup sedikit smear plugs) serta dibandingkan larutan Chitosan $0,37 \%$ ( smear layer bersih menyeluruh namun terjadi erosi yang besar pada dentin peritubulus dan dentin tubulus). Bila waktu aplikasi diperpanjang menjadi 5 menit pada berbagai konsentrasi tersebut, mengakibatkan efek erosi yang makin parah dengan peningkatan diameter tubulus dentin secara berlebihan dan kerusakan intertubulus dentin yang makin luas. ${ }^{8}$

Penelitian Darrag AM (2014) telah dilakukan secara in vitro menggunakan scanning electron microscope untuk membandingkan pembersihan smear layer di daerah sepertiga koronal-pertengahan-apikal saluran akar pada 50 buah gigi seri pertama rahang atas permanen setelah irigasi awal dengan $\mathrm{NaOCl} 2,5 \%$ dan irigasi akhir dengan larutan irigasi EDTA 17\%, Asam Sitrat 10\%, MTAD dan Chitosan 0,2\%. Hasil penelitian tersebut menunjukkan bahwa aplikasi $1 \mathrm{ml}$ larutan irigasi Chitosan $0,2 \%$ selama 3 menit, memiliki nilai rata-rata smear layer paling rendah pada ketiga bagian dari daerah saluran akar gigi tersebut. Efikasi pembersihan smear layer oleh larutan irigasi MTAD lebih baik dibandingkan EDTA 17\% dan Asam Sitrat 10\% di daerah sepertiga apikal saluran akar gigi. Nilai rata-rata smear layer paling rendah di bagian sepertiga koronal saluran akar gigi dan tertinggi di bagian sepertiga apikal saluran akar gigi. ${ }^{2}$

Penelitian Mathew SP (2017) telah dilakukan pada 40 gigi premolar yang di irigasi dengan $1 \mathrm{ml} \mathrm{NaOCl}$ $1 \%$ dan irigasi akhir selama 1 menit dengan larutan EDTA $17 \%$, Chitosan 0,2\%, Chitosan 0,5\% masing-masing sebanyak $5 \mathrm{ml}$. Evaluasi dengan atomic force microscopy memperlihatkan bahwa tidak ada perbedaan bermakna dalam kemampuan pembersihan smear layer dari ketiga jenis larutan irigasi yang di uji tersebut. Sedangkan nilai rata-rata kekasaran permukaan dentin di dinding saluran akar gigi yang terbesar, terjadi akibat paparan larutan irigasi EDTA 17\%, dibandingkan paparan larutan irigasi Chitosan 0,2\% dan Chitosan $0,5 \%$ yang cenderung lebih rendah. ${ }^{3}$

\section{PEMBAHASAN}

Chitosan yang salah satu pemanfaatannya kini sebagai larutan irigasi pada perawatan saluran akar gigi, dapat diperoleh dari proses deasetilasi chitin yang terdapat pada cangkang udang maupun kepiting. Deasetilasi chitin merupakan suatu proses penghilangan gugus asetil dari gugus asetamida $\left(-\mathrm{NHCOCH}_{3}\right)$ pada chitin melalui hidrolisis menggunakan larutan basa kuat dengan konsentrasi tinggi sehingga bertransformasi menjadi gugus asam amina $\left(-\mathrm{NH}_{2}\right)$ Chitosan. ${ }^{13}$

Perubahan struktur permukaan dentin saluran akar gigi yang diperlihatkan dalam penelitian Silva AP (2012), disebabkan oleh aplikasi larutan NaOCL 1\% sebagai irigasi awal berdampak merubah matriks kolagen dentin. Kondisi tersebut dilanjutkan oleh aksi demineralisasi dari larutan Chitosan sebagai bahan irigasi akhir yang bersifat khelasi sehingga mengakibatkan kelarutan dentin yang progresif bila waktu aplikasinya makin lama. Larutan Chitosan walaupun konsentrasinya rendah, memiliki kemampuan yang cukup untuk membersihkan smear layer dari permukaan dentin saluran akar gigi ${ }^{8}$. Perbedaan struktur dentin saluran akar gigi pada paparan larutan Chitosan 
dengan konsentrasi dan waktu aplikasi yang bervariasi tersebut juga menunjukkan fakta bahwa efisiensi larutan irigasi Chitosan dapat dipengaruhi antara lain oleh faktor lama waktu aplikasi serta konsentrasi larutan. Kesimpulan yang diperoleh dalam penelitian tersebut bahwa penggunaan $5 \mathrm{ml}$ larutan Chitosan $0,2 \%$ sebagai bahan irigasi akhir selama 3 menit, paling efisien untuk membersihkan smear layer dan smear plugs dengan efek erosi yang minimal. ${ }^{4}$

Penelitian Darrag AM (2014) yang sejalan dengan Silva AP (2012) juga menyimpulkan bahwa aplikasi $1 \mathrm{ml}$ larutan Chitosan 0,2\% selama 3 menit sebagai irigasi akhir, paling efisien membersihkan smear layer dibandingkan bahan irigasi lainnya yang diuji ( larutan EDTA 17\%, Asam Sitrat 10\% dan MTAD). ${ }^{2}$ Kemampuan pembersihan smear layer secara efektif dengan efek erosi dentin saluran akar gigi yang minimal oleh larutan Chitosan 0,2\% dari kedua hasil penelitian tersebut diatas, juga memberi keyakinan bahwa larutan Chitosan $0,2 \%$ berpotensi menjadi alternatif bahan irigasi terutama menggantikan fungsi EDTA 17\%. Penelitian Mathew SP (2017) yang sejalan dengan penelitian Silva AP(2012) juga telah membuktikan bahwa nilai rata-rata kekasaran permukaan dentin saluran akar gigi yang terbesar, terjadi akibat paparan larutan irigasi EDTA $17 \%$, dibandingkan paparan larutan irigasi Chitosan 0,2\% dan Chitosan 0,5\% yang cenderung lebih rendah. Perubahan topografi permukaan dentin saluran akar gigi pada penelitian Mathew (2017) tersebut, dijelaskan terjadi karena adanya perubahan kimiawi (dalam hal ini rasio kalsium-fosfat atau disingkat rasio $\mathrm{Ca} / \mathrm{P})$ yang diakibatkan paparan larutan irigasi. Perubahan topografi dentin saluran akar gigi yang paling besar terjadi akibat paparan EDTA $17 \%$, diketahui berkaitan dengan rasio $\mathrm{Ca} / \mathrm{P}$ yang lebih rendah pada dentin saluran akar gigi. Kondisi ini akan mengubah perbandingan antara komponen organik dan inorganik dentin yang konsekuensinya mempengaruhi sifat kekerasan, permeabilitas dan kelarutan dentin. Kesimpulan yang dapat diambil dari penelitian tersebut yaitu larutan irigasi Chitosan $0,2 \%$ merupakan agen khelasi efektif dengan efek perubahan dentin saluran akar gigi yang lebih kecil dibandingkan EDTA 17\%. ${ }^{3}$

Teori yang mendasari larutan Chitosan sebagai bahan irigasi yang mampu membersihkan smear layer pada dentin saluran akar gigi terkait kemampuan khelasinya, menyatakan bahwa pembentukan kompleks antara Chitosan dengan ion logam yang bertanggung jawab pada hilangnya ion kalsium (Ca) dari dentin dapat terjadi melalui mekanisme penyerapan, pertukaran ion dan pembentukan khelasi. ${ }^{14}$

\section{KESIMPULAN}

Penggunaan Larutan Chitosan 0,2\% sebagai bahan irigasi akhir, terbukti efektif menghilangkan smear layer dengan efek erosi dentin saluran akar gigi yang minimal dibandingkan larutan irigasi EDTA 17\%, Asam Sitrat 10\% dan MTAD. Penggunaan larutan Chitosan
$0,2 \%$ sebagai bahan irigasi menimbulkan efek perubahan kekasaran permukaan dentin saluran akar gigi yang lebih kecil dengan rasio $\mathrm{Ca} / \mathrm{P}$ yang lebih besar dibandingkan EDTA $17 \%$. Larutan Chitosan 0,2\% dengan kemampuan khelasinya yang efektif membersihkan smear layer serta sifatnya yang bikompatibel, berpotensi menjadi alternatif bahan irigasi pada perawatan saluran akar gigi.

\section{DAFTAR PUSTAKA}

1. Violich DR, Chandler NP. The smear layer in endodonticsa review. International Endodontic Journal.2010;43: 2-15.

2. Darrag AM. Effectiveness of different final irigation solutions on smear layer removal in intraradicular dentin. Tanta Dental Journal.2014; XX: 1-7.

3. Mathew SP, Pai VS, Usha G, Nadig RP. Comparative evaluation of smear layer removal by chitosan and ethylenediaminetetraacetic acid when used as irigant and its effect on root dentin: an in vitro atomic force microscopic and energy-dispersive x-ray analysis.Journal of Conservative Dentistry.2017;20: 245-250.

4. Silva PV, Guedes DFC, Pecora JD, Filho AMC. Time dependent effect of chitosan on dentin structure. Braz Dent J.2012;23(4):357-361.

5. Haapasalo M, Shen Y, Qian W, Gao Y. Irrigation in endodontics.Dent Clin N Am J.2010;54: 291-312.

6. Torabinejad M, Walton RE, Fouad AF. Endodontics principles and practice. $5^{\text {th }}$ ed.St.Louis: Elsevier Saunders.2015: 279-281.

7. Baron M, Liena C, Forner L, Palomares M, GonzalesGarcia C, Salmeron-Sanchez M. Nanostructural changes in dentin caused by endodontic irrigants. Med Oral Patol Oral Cir Bucal.2013;18:733-736.

8. Silva PV, Guedes DFC, Nakadi FV, Pecora JD, Filho AMC Chitosan: a new solution for removal smear layer after root canal instrumentation.International Endodontic Journal.2013;46: 332-338.

9. Mira PCS, Flamini LES, Guedes DFC,Filho AMC. Evaluation of the chelating effect of chitosan solubilized in different acids.Journal of Conservative Dentistry.2017;20(5): 297-301.

10. Hargreaves KM, Berman LH. Cohen's pathway of the pulp. $11^{\text {th }}$ ed.St.Louis: Elsevier Saunders. 2016: 249-265, 287-289.

11. Quintana RM, Jardine AP, Montagner F, Parolo CCF, Morgental RD, Kopper PMP. Effect of human, dentin, albumin and lipopolysaccharide on the antibacterial activity of endodontic activity of endodontic irrigants. Journal of Conservative Dentistry.2017;20(5): 341-345.

12. Zhang J, Xia W, Liu P, Cheng Q, Tahirou T, Gu W, Li B. Chitosan modification and pharmaceutical/biomedical application.Marine Drugs Journal.2010;8: 1962-198.

13. Azhar M, Efendi J, Syofyeni E, Lesi RM, Novalina S. Pengaruh konsentrasi $\mathrm{NaOH}$ dan $\mathrm{KOH}$ terhadap derajat deasetilasi kitin dari limbah kulit udang. EKSAKTA .2010;1(2):1-8.

14. .Rhazi M, Desbrieres J, Tolaimate A, Rinaudo M, Vottero $\mathrm{P}$, Alagui A. Influence of the nature of the metal ions on the complexation with chitosan. Application to the treatment of liquid waste. Eur Polym J.2002;38: 1523-1530. 